\section{Spatial pattern, water use and risk levels associated with the transmission of schistosomiasis on the north coast of Pernambuco, Brazil}

\author{
Padrão espacial, uso da água e níveis de risco \\ associados à transmissão da esquistossomose no \\ litoral norte de Pernambuco, Brasil
}

\author{
Helen Paredes 1 \\ Reinaldo Souza-Santos 1 \\ Ana Paula da Costa Resendes 1 \\ Marco Antônio Andrade de Souza 2,3 \\ Jones Albuquerque 4 \\ Silvana Bocanegra 4 \\ Elainne Christine de Souza Gomes 5 \\ Constança Simões Barbosa ${ }^{3}$
}

\title{
Introduction
}

\footnotetext{
${ }^{1}$ Escola Nacional de Saúde Pública Sergio Arouca,

Fundação Oswaldo Cruz, Rio de Janeiro, Brasil.

2 Departamento de Ciências

da Saúde, Universidade

Federal do Espírito Santo,

São Mateus, Brasil.

3 Centro de Pesquisas Aggeu Magalhães, Fundação Oswaldo Cruz, Recife, Brasil.

4 Departamento de

Estatística e Informática

Universidade Federal Rural

de Pernambuco, Recife,

Brasil.

5 Centro Acadêmico de

Vitória, Universidade Federal

de Pernambuco, Vitória de

Santo Antão, Brasil.

Correspondence

R. Souza-Santos

Departamento de Endemias

Samuel Pessoa, Escola

Nacional de Saúde Pública

Sergio Arouca, Fundação

Oswaldo Cruz.

Rua Leopoldo Bulhões 1480,

Rio de Janeiro, RJ 21041-210,

Brasil.

rssantos@ensp.fiocruz.br
}

\section{Abstract}

This study aimed to describe epidemiological aspects of schistosomiasis in Carne de Vaca, Goiana, on the coast of Pernambuco State, Brazil and analyze the spatial distribution of households' sanitary conditions and patterns of water contact. A parasitological survey was conducted between 2006 and 2007. An indicator was set to establish risk levels for schistosomiasis based on variables of water contact pattern, household characteris tics and proximity to the foci of vector snails. The prevalence was 18.71 in men and 15.96 in women. The age groups most affected were 20-29 years among men and 10-19 among women. The most common parasite load was 1-99 eggs per gram of feces. The prevalence was 17.3 cases per 100 inhabitants and its spatial distribution was not homogeneous. The Bayesian analysis proved unsatisfactory. It is concluded that schistosomiasis is endemic in Carne de Vaca and the risk indicator, based on geoprocessing, proved to be satisfactory, highlighting areas where the problem is more acute.

Schistosomiasis; Water Use; Spatial Analysis
Although schistosomiasis is already well known as an endemic disease, new cases of acute schistosomiasis infection have been discovered on the Pernambuco coast, Brazil. There, individuals carrying the disease have migrated to coastal areas in search of better living conditions but have most commonly ended up living in places with poor health conditions. These individuals have thereby contributed to the spread of the Schistosoma mansoni in snails' breeding sites on the coast. This phenomenon can be seen through new foci of the disease vectors found in coastal and tourist areas in Pernambuco, where peridomestic foci are commonly found, and even domestically in the houses of low income families. Active transmission sites have also been detected in summer homes frequented by individuals from the middle and upper social classes 1,2,3,4,5.

Factors such as exposure time, and intensity of human contact with water contaminated by human feces, are directly related to the incidence of schistosomiasis. The pattern of human contact with water is complex and highly variable, but it serves to provide an important explanation for the epidemiological differences between infected population groups. Nevertheless, factors such as socio-economic circumstances, water supply and the provision of sewerage services also have a strong influence on the occurrence of the disease 6,7 . 
According to Araújo et al. ${ }^{8}$, to better understand the processes involved in the transmission of the disease, it is necessary to use locality-level research. Nevertheless, knowledge generated by parasitological research should be combined with modern epidemiological analysis in order to provide answers to environmental, ecological and behavioral questions involved in the spatial dynamics of endemic disease transmission 8 .

According to Santos et al. ${ }^{9}$, the analysis of spatial data and the construction of risk maps provide tools for epidemiology which contribute to various studies, subsidizing the intervention strategies of public policies with the etiological exploration of health related events.

In light of the above, this study aims to describe factors associated with schistosomiasis in the village of Carne de Vaca, Goiana city, on the north coast of Pernambuco and analyze the spatial distribution of household sanitary conditions and patterns of human contact with water, aiming to create an estimate of risk for disease occurrence.

\section{Methodology}

The study area is the village of Carne de Vaca, in the District of Ponta de Pedra, Goiana City, located on the north coast of Pernambuco, Brazil. It is bordered to the north by Paraíba state, to the south by Itaquitinga, Igarassu, Itapissuma and Itamaracá municipalities, to the east by the Atlantic Ocean and to the west by Condado and Itambé 10 .

The village has approximately 1,041 households and 1,600 people distributed in 70 blocks. Most houses located in the central part of Carne de Vaca have piped water, distributed on alternate days, requiring the need for tanks and wells. This same central area is dissected by streams known locally as maceió (a lagoon formed by the sea at high tides and by rainwater). These streams extend to the southern sector, and only in a stretch in the middle of the village pass through pipes. Part of the village's sewage is dumped in these streams without any treatment.

The water is not supplied by the state company (COMPESA), but is pumped from the main reservoir and from an artesian well, then chlorinated in the local water supply center. This center also has taps (popularly called the fountain), where some people fetch water for different activities, including washing clothes.

There is a second water source with taps for public use whose water, according to information from local residents, comes from that first distribution center. Another site also used to fetch water and wash clothes is a small water source known as Riacho Doce. The houses in the northern part of Carne de Vaca are not supplied with waters from the center, but from tanks with pumps which pipe water to the residents' taps.

Several economic activities are carried out in the village, including subsistence farming, seafood and crab fishing, trade and domestic services, among others.

The study was conducted in two phases. The first involved a parasitological investigation of the population's feces, with the aim of diagnosing the disease using the Kato-Katz method and examining two slides for each patient between November 2006 and February 2007. The tests were performed on 1,100 individuals, however in 20 of the 70 blocks in the site no individuals were examined, as these were only summer houses.

According to the local Family Health Program, there are more than 1,000 people living in Carne de Vaca village. Since there is no official estimate, we used the total population sampled for calculating the prevalence by blocks. Therefore, the total number of positive individuals, according to the results of parasitological examination was divided by the population sampled in each block, multiplying the result by 100 .

In the second phase, in March 2007, formal interviews were carried out with the head of each sampled household. A semi-structured questionnaire was used with questions about household characteristics and human water contact.

Sampling of houses was carried out for convenience. Since the blocks presented homogeneous household sanitary conditions, and socio-economic characteristics, the objective was to characterize them based on the information obtained in each home.

A total of 202 individuals of both sexes were interviewed, all of whom were residents in the village of Carne de Vaca. Likewise from the 70 existing blocks, 26 were not included because they featured only summer houses or businesses, or because residents were not available to be interviewed. Thus, $62 \%$ of the blocks are represented in the sample. Of these 26 blocks not involved, 20 were the same ones that were not sampled during the parasitological investigation. The results of the first stage were matched with data from the second, according to the residential block of each individual.

Data were entered and stored in Microsoft Access software and analyzed using SPSS, version 13.0 (SPSS Inc., Chicago U.S.A.). The Chisquare statistic was used to verify the null hypothesis of proportions. $\mathrm{p}<0.05$ was considered significant 11 .

A digital block-level polygon map of Carne de Vaca was constructed using the program Ma- 
pInfo Professional 6.0 from the croquis made by technicians at the CPqAM schistosomiasis laboratory (Centro de Pesquisa Aggeu Magalhaes/ Fiocruz).

\section{Spatial analysis}

The prevalence per block (crude rates) was recalculated based using the global empirical Bayesian approach, producing adjusted rates. This method aims to correct possible distortions when working with small numbers in each block, weighing each value by the global average 12 .

The risk indicator is based on responses obtained through the application of questionnaires, and the answers were transformed into dichotomous variables. The variables that make up the indicator represent the following elements: houses per block that did not have a well; that drain water from their bathroom into the pit; that do not have piped water; with people who have water contact when leaving home in the dry and rainy season; people who frequent the Riacho Doce and the water reservoir in the dry and rainy seasons. We divided the total number of houses with a positive answer by the total number of houses sampled in each block. Each variable can range from 0 to 1 .

In addition, two other variables were considered in the construction of the indicator - those for blocks located near open streams, and also blocks with snail vector foci 13 . For the construction of these variables the influence area (buffer) was calculated, with a 60 meter radius, surrounding the positive foci of Biomphalaria glabrata for schistosomiasis to attribute higher risk to the blocks within this influence area.

These two variables were created using spatial operations between layers, where the blocks containing the buffer influence areas or those with open streams were identified. For these blocks a value of " 1 " was assigned. The value " 0 " was assigned to the other blocks.

The indicator was constructed from the total proportions of each variable obtained by block plus the values that represent whether the block has an open stream or not and if the block has snail foci or not. The risk indicator value obtained, based on the pattern of water contact, proximity to vector snail foci, and household sanitary characteristics for each block, could vary from 0 to 11 .

To establish the level of risk for schistosomiasis, four strata were determined and attributed to the blocks, as follows: blocks whose risk indicator value was between 0 and 2.75 were regarded as low risk; those with an indicator ranging from 2.751 to 5.5 were medium-low risk; medium-hi- gh risk blocks were those with an indicator value ranging between 5.51 and 8.25 ; while those with an indicator value of between 8.251 and 11 were considered high risk.

The local Moran index (LISA) was used for the spatial pattern study, using a neighborhood matrix covering a 170 meter distance. The local Moran index produces a specific standard value (values of attributes subtracted from the average and divided by standard deviation) to each area (block), allowing the identification of cluster areas with significant patterns of spatial association. The values produced correspond to those recorded for the four quarters of the Moran scatter diagram 14 where:

Quadrant $1(+/+)$ indicates the presence of blocks with positive standard value and with average normalized values of the positive neighboring blocks, that is, both values are positive; quadrant 2 (-/-) located the blocks with a negative value and average normalized values of negative neighboring blocks, in other words where both values are negative. Thus, quadrants 1 and 2 (Q1 and Q2) represent positive spatial association areas taking into account that the site includes neighbors with similar values (homogeneous areas). Quadrant 3 (+/-) includes blocks with a positive standard value and negative average normalized values of neighboring blocks; finally, quadrant 4 $(-/+)$ represents the blocks with a negative standard value and positive average normalized values of neighboring blocks. These latter indicate heterogeneous (intermediate) areas 14 .

For the determination of higher, lower and intermediate risk blocks for schistosomiasis, representative maps, called Box Maps, for the Moran index of the risk indicator for schistosomiasis were produced with the following criteria: highest risk area with aggregate blocks in quadrant Q1 (+/+); lower risk areas with aggregate blocks in quadrant Q2 (-/-); intermediate transmission risk areas with aggregate blocks in quadrants Q3 (+/-) and Q4 (-/+). To visualize the areas of statistically significant spatial autocorrelation $(\mathrm{p}<$ 0.01 ) representative maps for the risk indicator of the Moran Map were used.

The spatial statistic and the creation of buffers and operations between layers were developed using TerraView software version 3.1.4 (Instituto Nacional de Pesquisas Espaciais; http://www. dpi.inpe.br/terraview).

The project was approved by the Ethics Committee of the Escola Nacional de Saúde Pública Sergio Arouca/Fiocruz. 


\section{Results}

The findings from the study show that Carne de Vaca village can be considered medium-endemic for schistosomiasis with a prevalence of 17.3 cases per 100 inhabitants in the year 2007.

Parasitological examinations were performed on 1,100 residents of the village, of whom $48.1 \%$ were male. The male/female ratio of individuals with the disease was 1.08:1, and there was no statistically significant difference between the sexes ( $\mathrm{p}>0.05$ ).

Among men, the most affected age group was $20-29$ years (16.31\%). The most affected age group among women was $10-19$ years (12.63\%), and the range of 30-39 years was very close to that of the most affected age group (Table 1). Also there was no statistically significant difference between sexes in any of the age groups.

The parasite load of 1-99 eggs per gram of feces was the most frequent among individuals, in both sexes and all age groups (Table 2). Few had burdens above 500 eggs per gram of feces, with a twelve year-old child presenting a load of 1,992 eggs per gram of feces.

Regarding household conditions, $63.37 \%$ of homes had four or more residents. The main destination of toilet sewage was the pit (93.06\%). Only $0.49 \%$ of bathroom sinks are directly linked to the maceiós and $6.43 \%$ flowed to other destinations, usually in the bush. Regarding the supply of piped water, $32.67 \%$ of households receive water daily, $2.97 \%$ had a weekly supply, and $48.52 \%$ had another type of distribution regularity, usually on alternate days. A total of $80.7 \%$ developed other strategies for water catchment, such as tank construction, storage of water in own reservoirs or use of water from the wells of neighboring residents. Most houses had no well (59.9\%).
Clothes washing in the home was reported in $68.81 \%$ of households, $2.5 \%$ in the stream, $1 \%$ in the main reservoir, $2.5 \%$ at home and in the Riacho Doce, $2.5 \%$ in the main reservoir and the Riacho Doce and $12.8 \%$ in other places, such as faucets available in the main water tanks of the village (known as a fountain) or in the main reservoir known as "Freitas fountain".

The water most used for drinking was that of the main reservoir during the dry and rainy seasons $(62.37 \%$ and $57.43 \%$, respectively). For baths and cooking, the use of piped water was mentioned by $45.54 \%$ and $44.06 \%$ of the population, respectively. The ratio of houses with piped water to those without was 5.31:1. In these households, the water supply for drinking, bathing and/or cooking was mainly daily for both dry and rainy seasons. The differences between households with piped water and those with nonpiped water concerning the illness risk were not statistically significant $(\mathrm{p}>0.05)$.

\section{Water contact}

92.47 percent of people that reported in the interview that they had no contact with water chose to leave their homes in the dry season. In the rainy season the opposite reply was reported by $46 \%$ of respondents.

The ratio of individuals with schistosomiasis, who also have contact with water when they leave home in the dry season in relation to the rainy season was 0.6:1 ( $p>0.05)$.

The ratio of people who frequent the Riacho Doce to those who do not frequent during the dry period was 1.72:1 ( $\mathrm{p}<0.05)$. On the other hand, this ratio was 0.26 : 1 during the rainy season. There was also a statistically significant difference in these periods $(\mathrm{p}<0.05)$.

Table 1

Prevalence (per 100 inhabitants) of schistosomiasis according to age group and sex. Carne de Vaca, Goiana, Pernambuco State, Brazil, $2006-2007$.

\begin{tabular}{|c|c|c|c|c|c|c|c|c|c|}
\hline \multirow{2}{*}{$\begin{array}{l}\text { Age group } \\
\text { (years) }\end{array}$} & \multicolumn{3}{|c|}{ Male } & \multicolumn{3}{|c|}{ Female } & \multicolumn{3}{|c|}{ Total } \\
\hline & Population & Positives & Prevalence * & Population & Positives & Prevalence * & Population & Positives & Prevalence * \\
\hline Up to 9 & 99 & 7 & 7.1 & 100 & 3 & 3.0 & 199 & 10 & 5.0 \\
\hline $10-19$ & 109 & 26 & 23.9 & 99 & 24 & 24.2 & 208 & 50 & 24.0 \\
\hline $20-29$ & 76 & 31 & 40.8 & 90 & 21 & 23.3 & 166 & 52 & 31.3 \\
\hline $30-39$ & 88 & 18 & 20.5 & 103 & 23 & 22.3 & 191 & 41 & 21.5 \\
\hline$\geq 40$ ** & 141 & 14 & 9.9 & 168 & 18 & 10.7 & 310 & 32 & 10.3 \\
\hline Unreported & 16 & 3 & 18.8 & 10 & 2 & 20.0 & 26 & 5 & 19.2 \\
\hline Total & 529 & 99 & 18.71 & 570 & 91 & 15.96 & 1100 & 190 & 17.3 \\
\hline
\end{tabular}

* Per 100 inhabitants;

** No information on sex for one individual. 
Number of eggs per gram of feces, stratified by age and sex. Carne de Vaca population, Goiana, Pernambuco State, Brazil, $2006-2007$.

\begin{tabular}{|c|c|c|c|c|c|c|c|c|c|c|c|}
\hline \multirow{3}{*}{$\begin{array}{l}\text { Age groups } \\
\text { (years) }\end{array}$} & \multirow[t]{3}{*}{ Population } & \multicolumn{10}{|c|}{ Number of eggs per gram of feces * } \\
\hline & & \multicolumn{2}{|c|}{0} & \multicolumn{2}{|c|}{$1-99$} & \multicolumn{2}{|c|}{$100-499$} & \multicolumn{2}{|c|}{500} & \multicolumn{2}{|c|}{ Total } \\
\hline & & n & $\%$ & n & $\%$ & n & $\%$ & n & $\%$ & $\mathrm{n}$ & $\%$ \\
\hline \multicolumn{12}{|l|}{ Male } \\
\hline Up to 9 & 99 & 92 & 21.40 & 5 & 5.95 & 2 & 15.38 & 0 & 0.00 & 7 & 7.07 \\
\hline $10-19$ & 109 & 83 & 19.30 & 21 & 25.00 & 5 & 38.46 & 0 & 0.00 & 26 & 26.26 \\
\hline $20-29$ & 76 & 45 & 10.47 & 27 & 32.14 & 3 & 23.08 & 1 & 50.00 & 31 & 31.31 \\
\hline $30-39$ & 88 & 70 & 16.28 & 15 & 17.86 & 2 & 15.38 & 1 & 50.00 & 18 & 18.18 \\
\hline$\geq 40$ & 141 & 127 & 29.53 & 13 & 15.48 & 1 & 7.69 & 0 & 0.00 & 14 & 14.14 \\
\hline Unreported & 16 & 13 & 3.02 & 3 & 3.57 & 0 & 0.00 & 0 & 0.00 & 3 & 3.03 \\
\hline Total & 529 & 430 & 100.00 & 84 & 100.00 & 13 & 100.00 & 2 & 100.00 & 99 & 100.00 \\
\hline \multicolumn{12}{|l|}{ Female } \\
\hline Up to 9 & 100 & 97 & 20.25 & 2 & 2.94 & 1 & 5.00 & 0 & 0.00 & 3 & 3.30 \\
\hline $10-19$ & 99 & 75 & 15.66 & 15 & 22.06 & 7 & 35.00 & 2 ** & 66.67 & 24 & 26.37 \\
\hline $20-29$ & 90 & 69 & 14.41 & 14 & 20.59 & 6 & 30.00 & 1 & 33.33 & 21 & 23.08 \\
\hline $30-39$ & 103 & 80 & 16.70 & 17 & 25.00 & 6 & 30.00 & 0 & 0.00 & 23 & 25.27 \\
\hline$\geq 40$ & 168 & 150 & 31.32 & 18 & 26.47 & 0 & 0.00 & 0 & 0.00 & 18 & 19.78 \\
\hline Unreported & 10 & 8 & 1.67 & 2 & 2.94 & 0 & 0.00 & 0 & 0.00 & 2 & 2.20 \\
\hline Total & 570 & 479 & 100.00 & 68 & 100.00 & 20 & 100.00 & 3 & 100.00 & 91 & 100.00 \\
\hline General total & 1,100 & 909 & & 152 & & 33 & & 5 & & 190 & \\
\hline
\end{tabular}

* No information on sex for one individual;

** The range $\geq 500$ includes a single record of a 12 year old girl with a parasite load over 1,000 eggs per gram of feces (1,992 eggs per gram).

The main reason for contact with the waters of the Riacho Doce reported by the interviewees, during the rainy and dry seasons, was swimming/leisure $(42.08 \%$ and $9.9 \%$ respectively). Of the respondents, $36.14 \%$ and $78.71 \%$ did not frequent the Riacho Doce in dry and rainy periods, respectively. The frequency of visits to the main reservoir was reported at a ratio of 2.74:1 between visitors and non visitors during the dry season, a statistically significant difference $(p<0.05)$. During the rainy season the ratio was $1.72: 1$, also a statistically significant difference $(\mathrm{p}<0.05)$.

The main reason for contact with the waters of the reservoir reported by the interviewees, during the dry and rainy periods, was water catchment (57.92\% and 50\% respectively). Of the respondents, $26.73 \%$ and $36.63 \%$ did not frequent the reservoir in the dry and rainy periods, respectively.

\section{Spatial analysis}

The thematic map (Figure 1a) shows that a higher crude prevalence is located in a block in the central part of the village. However, there was only one individual examined in this block. Only two blocks from the central part showed prevalence of between 60 and 80 . However, there is no evident distribution pattern in the other areas of the village. After adjusting using the Bayesian method (Figure 1b) there was some homogeneity in the rates between the blocks, except in the central portion, where the highest rates are pointed out. It is important to emphasize that there is no information available for 20 of the 70 blocks in Carne de Vaca and that there were no cases of schistosomiasis in 15 of the blocks studied.

The classification of the blocks according to the risk indicator (Figure 2a) showed that no site was classified as high risk (8.251-11). A total of 13 blocks were included in the high-medium risk interval of 5.51-8.25, with two of them located at snail foci. The range presenting the lowest risk is the $0-2.25$ and included four blocks. The other 27 sites were classified as being of low-medium risk.

The distribution of blocks, according to the risk indicator, in the Moran scatter diagram represented in the Box Map (Figure 2b) indicated 18 areas of highest risk for schistosomiasis, all located in the central sector of the village. Areas with lower risk and areas of intermediate risk 
Figure 1

Prevalence of crude schistosomiasis (100 inhabitants) per block (1a) and adjusted prevalence of schistosomiasis (100 inhabitants) by the global empirical Bayesian method (1b). Carne de Vaca, Goiana, Pernambuco State, Brazil, 2006 and 2007.

1a) Prevalence

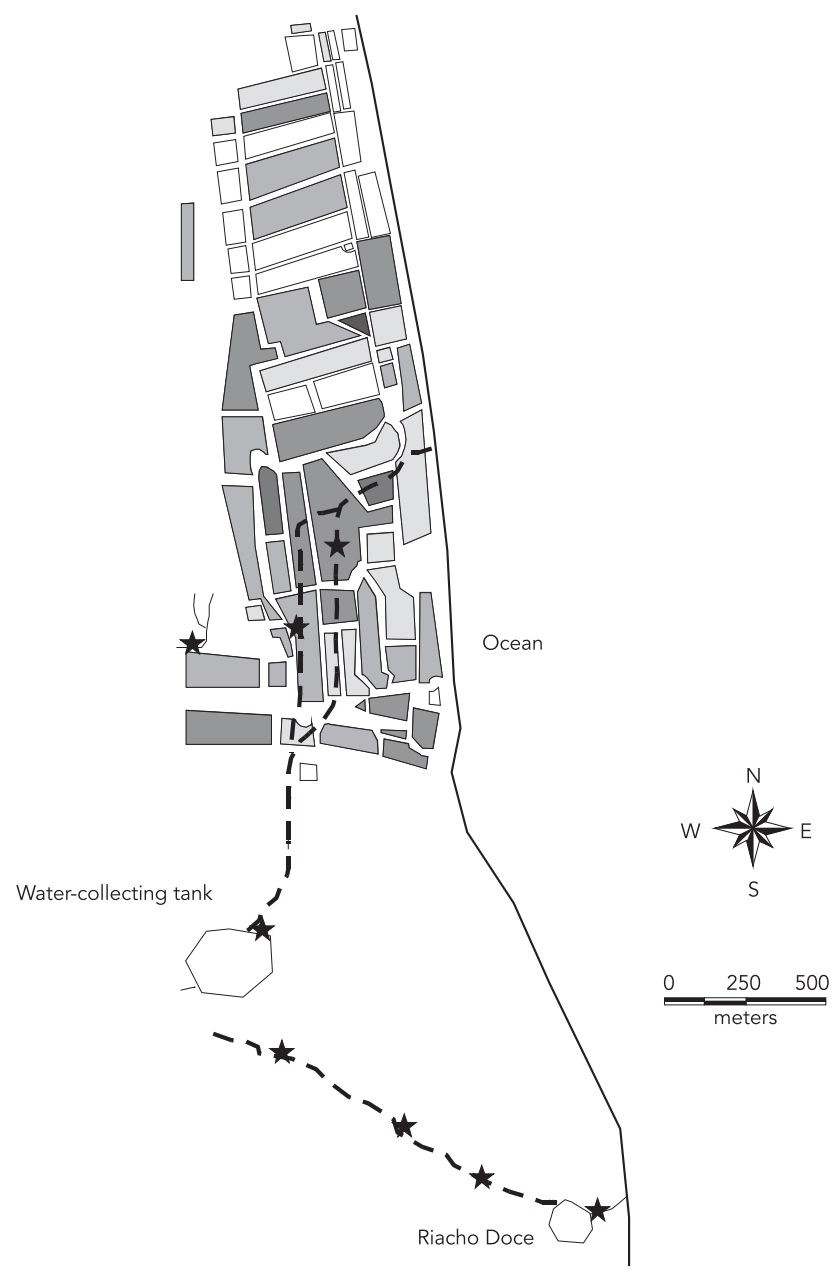

1b) Adjusted prevalence Bayesian approach

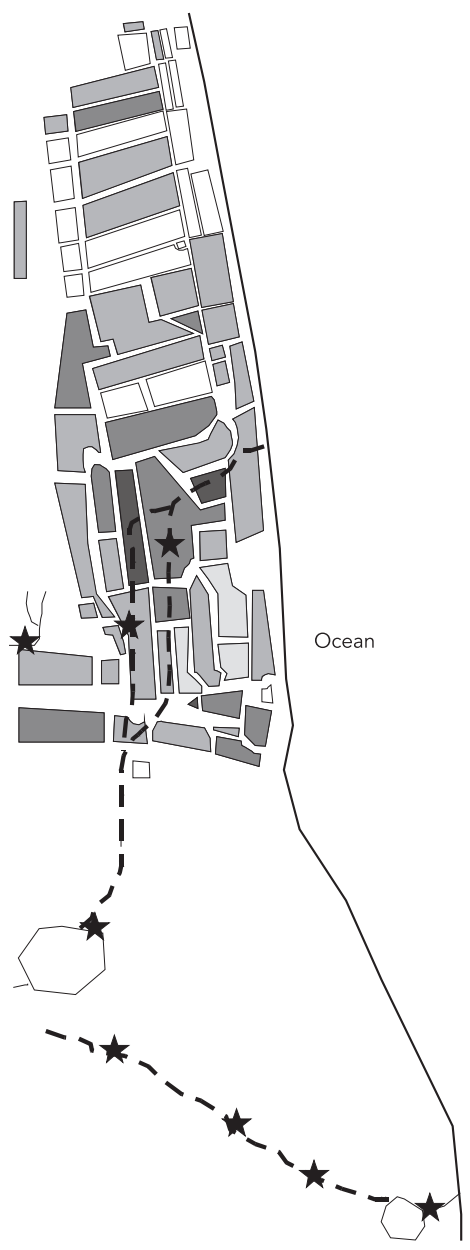

Prevalence per 100 inhabitants

$\square$ No information

$\square 0 \quad$ (15)

$\square \quad 1-20 \quad$ (17)

20-60 (14)

$\square \quad 60-80 \quad$ (2)

80-100 (1)

Breeding sites

- - Stream / Maceió
Adjusted prevalence

$\square$ No information

$\begin{array}{lll}\square & 0-10 \quad \text { (3) }\end{array}$

$\square \quad 10-20 \quad$ (32)

$\square \quad 20-30 \quad$ (11)

प $30-50 \quad$ (3)

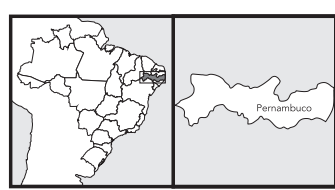


Figure 2

Risk indicator for schistosomiasis. Carne de Vaca, Goiana, Pernambuco State, Brazil, 2007.
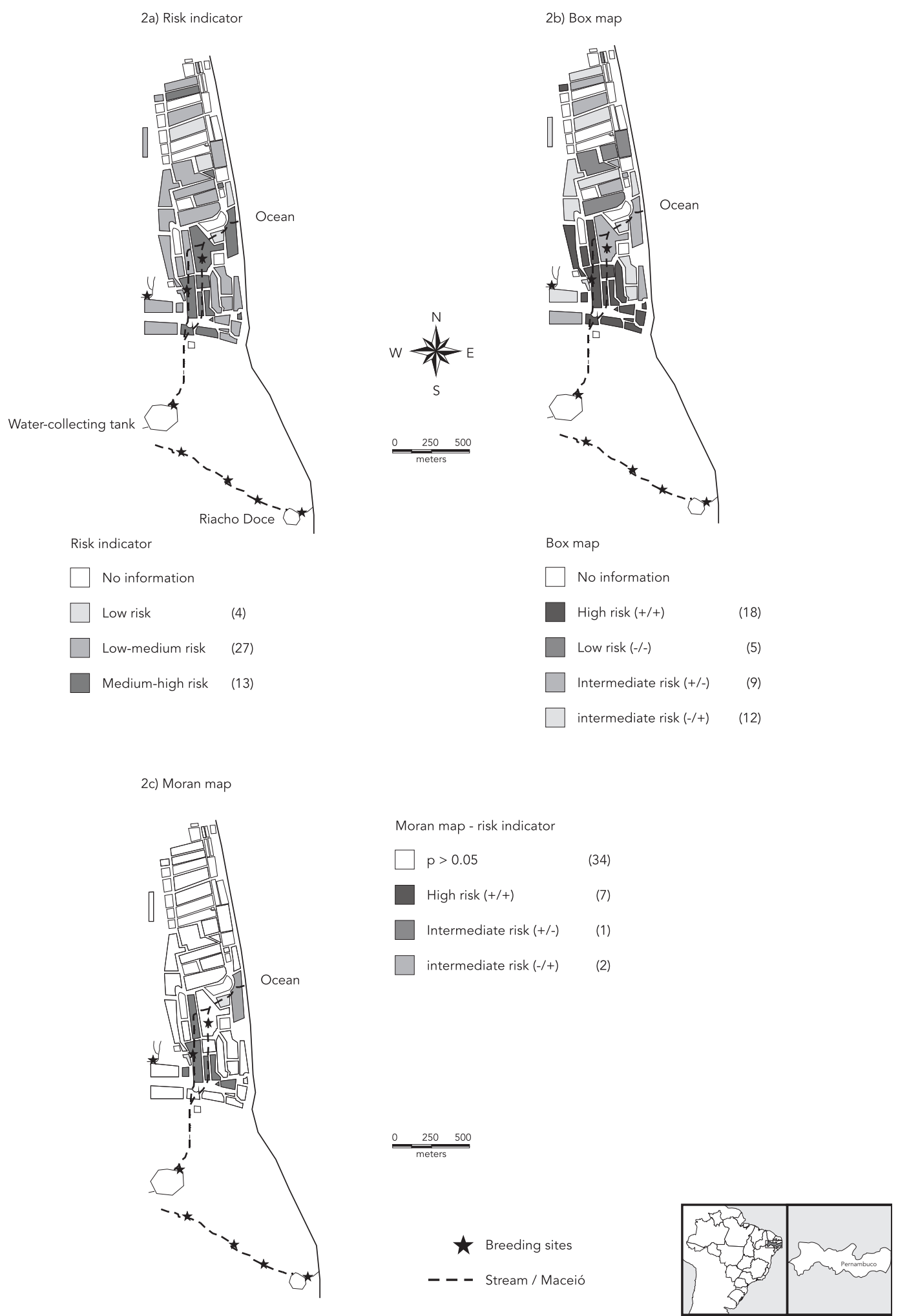
for occurrence of the disease were located in the north and central portions with some irregularity in the distribution.

In the representation according to the Moran Map (Figure 2c), seven blocks stand out as highest risk areas for schistosomiasis, all in the central part of the village, most of them next to streams and foci. Another three blocks were identified as intermediate risk for the occurrence of the disease. In the other blocks the spatial autocorrelation of the risk indicator showed no statistical significance.

\section{Discussion}

The findings of this study show that Carne de Vaca village can be considered of medium endemicity of schistosomiasis, with a prevalence of 17.3 cases per 100 inhabitants in the year 2007 .

Regarding the total population with positive feces examinations for schistosomiasis in the study, $13.81 \%$ expelled between 1-99 eggs per gram of feces, being considered a light parasite load. The intensity of infection by $S$. mansoni is a better morbidity indicator than prevalence, as used in the determination of serious for$\mathrm{ms}$ of the disease, especially the hepatosplenic form ${ }^{11}$. However, young people were found carrying the disease (10-19 age group) with a high parasite load $(\geq 500)$, which may indicate recent and intense exposure to water contaminated by the parasite 8 .

The results showed no statistical association between infection with $S$. mansoni and sex in Carne de Vaca. This can be partially explained by no differentiation in daily practices between individuals of both sexes in the village, such as labor and leisure activities that can give rise to more contact with water collections.

The population contact pattern is complex and highly variable; however this is an aspect where an explanation can be found for the epidemiological differences between those infected. It is known that different patterns of contact with collections of natural waters will lead to distinct epidemiological patterns, since it can be reasonably expected that people who have more contact with snail breeding sites have a greater chance of becoming infected 7 .

The frequency of visits to the main water reservoir, where the presence of infected vector snails can also be found, is reported by many residents ${ }^{13}$. The consumption of water from the main reservoir for drinking was reported by most residents who stated that this is the best quality of water for this purpose. According to reports, during the summer, when the tourist flow in- creases in the village, the supply of piped water becomes irregular which provides a further increase in the direct catchment of water in the reservoir.

Many residents reported the requirement of water contact when leaving home, especially during the rain. This is an even more serious problem in households located in blocks where there are the "maceiós", as in many cases the waters invade their houses. This fact was evidenced by our results which pointed to a higher prevalence of schistosomiasis in people who have contact with water when leaving home during the rainy season.

The frequency of visitations to Riacho Doce was also reported by many residents, however, the presence of vector snails was not observed in this site 13 . Still, the results showed that individuals who visit the Riacho Doce are more prone to illness both in the dry and rainy seasons when compared to non-visitors, the same applying to visitors to the main reservoir in both periods. In this case, the population infection reflects earlier exposure conditions, as according to reports from local people there were snails in the past but not confirming that they were disease vectors. The fact can also be explained by the habit of visiting the Riacho Doce and other habits that expose them to illness risk.

\section{Spatial analysis}

The crude prevalence mapping showed that the disease does not occur in 15 of the blocks though sometimes these same areas are next to others with medium or high rates. The event is related to the water contact pattern by individuals, and not simply by residence location. However, if this residence is next to a water collection, this neighborhood becomes a risk factor.

The adjusted prevalence showed that, except in central areas, where there are streams and foci of $B$. glabrata (higher risk), all the other areas are virtually at the same risk. The results described here confirm the risk to the central part of the village. However, concerning the other blocks, the adjustment was not satisfactory because, as pointed out in the previous paragraph and in the study carried out by Kloos et al. 15, disease transmission occurs where there is a presence of $B$. glabrata in habitats with domestic and entertainment uses, among others.

Despite the satisfactory result for the analysis developed by Souza et al. 16, in the case of this study, the estimate using the global empirical Bayesian method was not appropriate. This fact can also be related to the number of blocks without available information. 
Concerning the risk indicator, it showed Carne de Vaca as a medium-risk area for schistosomiasis, confirming what was proven by the calculation of crude prevalence in 2007, with $17.3 \mathrm{ca}$ ses per 100 inhabitants. Despite the fact that the block classification from the indicator may vary from 0 to 11 , the maximum value observed was 8.23. Therefore the blocks are classified as low medium-low or medium-high risk. It is important to emphasize that all blocks where the foci and streams were located are under low-medium or medium-high risk.

When analyzing the indicator through the Box Map, it is observed that 18 blocks are under higher risk of illness, located in the center of the village. Despite all these blocks having presented the highest proportion of people with intense contact with water collections and households whose characteristics favored the risk of schistosomiasis, only seven of these blocks did not lose their statistical significance when the spatial autocorrelation represented by the Moran Map was observed.

About the spatial statistics used, it is important to emphasize that the software used makes no edge effects correction ${ }^{12}$. In other words, the results for the blocks that are nearest to the boundary of the locality may be biased, tending to be greater than those inside the locality, since there are no blocks outside the edge of the locality. Moreover, in the central area of Carne de Vaca village, there are four blocks that were not sampled during the interview and during the parasitological survey.

The use of the risk indicator, which took into account the household characteristics and the water contact pattern of individuals in each block, proved to be satisfactory. This fact was reinforced by both the Box Map and the Moran Map, techniques that only emphasized the blocks that need further attention to improvements in sanitation conditions and strengthening health education.

In Carne de Vaca it was observed that contact with water collections is part of the daily life of the population, according to its needs, the location's physical structure and environment characteristics. Thus, the risk indicator as a tool of study proved to be important because, although not necessarily indicating a higher risk for all blocks with the highest prevalence, it points to the central region of the village as the area where the problem is more relevant. It is important to emphasize that most of the local population resides, in the central part of the village, which suggests that the processes involved in the dynamics of disease transmission occur with greater intensity in this site and its population.

A simple interpretation of the bivariate analysis of our results may indicate that there is no association between the occurrence of schistosomiasis and the pattern of water contact, proximity to snail vector foci, or sanitary and household characteristics. However, the association became evident when comparing the results of the mapping of the risk indicator with the distribution of prevalence. Furthermore, we note that most residents confirm the visitation to the main water reservoir to obtain drinking water, a variable included in the risk indicator that may be related to oral and/or skin infection.

From the standpoint of schistosomiasis ecoepidemiology, our results reinforce what is already known in the scientific literature. Furthermore, our study tested two methods that are suggested in the scientific literature 17,18 , namely the Bayesian approach and GIS techniques in epidemiological analysis of communicable diseases. The results of the first method were not satisfactory for the study of schistosomiasis at the local level, different to the results reported by Clements et al. 18 . However, the risk indicator built on GIS techniques, showed promise in identifying high-risk places within a small area. These may be of great value to the schistosomiasis surveillance and control services.

The results observed in this study describe a scenario of schistosomiasis dynamics on the Pernambuco coast. However, for a better understanding of local dynamics in time, besides a spatial one, the use of computing tools such as simulators, is necessary, to analyze scenarios and the predictability of the expansion of the disease 19 .

In this context, the crossing of the data with satellite imagery, taking into account the environmental characteristics, such as climate, topography, and vegetation, applied to the model based on Cellular Automata, has been shown to be promising 19 


\section{Resumo}

O estudo objetivou descrever aspectos epidemiológicos da esquistossomose em Carne de Vaca, litoral de Pernambuco, Brasil, e analisar a distribuição espacial das condições de esgotamento sanitário e padrão de contato com a água. Foi realizado um inquérito parasitológico entre 2006 e 2007, e criado indicador de risco para a esquistossomose com base em variáveis do padrão de água de contato, características do agregado familiar e da proximidade com focos de moluscos vetores. A prevalência em homens foi de 18,71, e 15,96 em mulheres. A faixa etária mais acometida em homens e mulheres foi de 20-29 e 10-19, respectivamente. A carga parasitária mais freqüente foi de 1-99 ovos por grama de fezes. A prevalência foi de 17,3 casos por 100 habitantes e sua distribuição espacial não foi homogênea. A estatística Bayesiana não se mostrou satisfatória. Conclui-se que a esquistossomose é endêmica em Carne de Vaca e que o indicador de risco com base em geoprocessamento revelou-se satisfatório, destacando as áreas onde o problema é mais relevante.

Esquistossomose; Usos da Água; Análise Espacial

\section{References}

1. Barbosa CS, Silva CB, Barbosa FS. Esquistossomose: reprodução e expansão da endemia no Estado de Pernambuco no Brasil. Rev Saúde Pública 1996; 30:609-16.

2. Barbosa CS, Barbosa FS. Padrão epidemiológico da esquistossomose em comunidade de pequenos produtores rurais de Pernambuco, Brasil. Cad Saúde Pública 14:129-37.

3. Barbosa CS, Pieri OS, Silva CB, Barbosa FS. Ecoepidemiologia da esquistossomose urbana na ilha de Itamaracá, Estado de Pernambuco. Rev Saúde Púbica 2000; 34: 337-41

4. Barbosa CS, Domingues ALC, Abath F, Montenegro SML, Guida U, Carneiro J, et al. Epidemia de esquistossomose aguda na praia de Porto de Galinhas, Pernambuco, Brasil. Cad Saúde Púbica 2001; 17:725-8.

\section{Contributors}

H. Paredes, R. Souza-Santos and C. S. Barbosa were involved in the study design, field work, analysis and article write-up. A. P. C. Resendes, J. Albuquerque and S. Bocanegra participated in the data analysis and article write-up. M. A. A. Souza contributed towards the study design, field work, discussion of the results and article write-up. E. C. S. Gomes participated in the discussion of the results and article write-up.
5. Barbosa CS, Araújo KC, Antunes L, Favre T, Pieri OS. Spatial distribution of schistosomiasis foci on Itamaracá Island, Pernambuco, Brazil. Mem Inst Oswaldo Cruz 2004; 99 Suppl I:79-83.

6. Lima-Costa MFF, Rocha RS, Magalhães MH, Katz N. Um modelo hierárquico de análise das variáveis sócio-econômicas e de padrões de contatos com águas associados à forma hepatosplênica da esquistossomose. Cad Saúde Pública 1994; 10 Suppl 2:241-53.

7. Moza PG, Pieri OS, Barbosa CS, Rey L. Fatores sócio-demográficos e comportamentais relacionados à esquistossomose em uma agrovila da zona canavieira de Pernambuco, Brasil. Cad Saúde Pública 1998; 14:107-15. 
8. Araújo KCGM, Resendes APC, Souza-Santos R, Silveira Jr. JC, Barbosa CS. Análise espacial dos focos de Biomphalaria glabrata e de casos humanos de esquistossomose mansoni em Porto de Galinhas, Pernambuco, Brasil, no ano de 2000. Cad Saúde Pública 2007; 23:409-17.

9. Santos MS, Noronha PC. Padrões espaciais de mortalidade e diferenciais sócio-econômicos na cidade do Rio de Janeiro. Cad Saúde Pública 2001; 17:1099-110.

10. Ministério de Minas e Energia. Projeto cadastro de fontes de abastecimento de águas subterrâneas Pernambuco. Diagnóstico do Município de Goiana. Recife: Secretaria de Planejamento e Desenvolvimento Energético, Secretaria de Geologia, Mineração e Transformação Mineral, Ministério de Minas e Energia/Programa de Desenvolvimento Energético dos Estados e Municípios/Serviço Geológico do Brasil; 2005.

11. Bina JC, Prata A. Esquistossomose na área hiperendêmica de Taquarendi. I - infecção pelo Schistosoma mansoni e formas graves. Rev Soc Bras Med Trop 2003; 36:211-6.

12. Bailey TC, Gastrell AC. Interactive spatial data analysis. Essex: Longman Scientific \& Technical; 1995.

13. Souza MAA, Barbosa VS, Albuquerque JO, Bocanegra S, Souza-Santos S, Paredes H, et al. Aspectos ecológicos e levantamento malacológico para identificação de áreas de risco para transmissão da esquistossomose mansoni no litoral Norte de Pernambuco. Iheringia, Sér Zool; in press.

14. Câmara G, Monteiro AM, Fucks SD, Carvalho MS Análise espacial e geoprocessamento. In: Druck $\mathrm{S}$, Câmara G, Carvalho MS, Monteiro AMV, organizadores. Análise espacial de dados geográficos. Brasília: Embrapa Cerrados; 2002. p. 20-47.
15. Kloos H, Passos LKJ, LoVerde P, Oliveira RC, Gazzinelli A. Distribution and Schistosoma mansoni infection of Biomphalaria glabrata in differents habitats in a rural área in the Jequitinhonha Valley, Minas Gerais, Brazil: Environmental and epidemiological aspects. Mem Inst Oswaldo Cruz 2004; 99:673-81.

16. Souza VW, Barcellos CC, Brito AM, Carvalho MS, Cruz OG, Albuquerque MFM, et al. Aplicação do modelo bayesiano empírico na análise espacial da ocorrência de hanseníase. Rev Saúde Pública 2001; 35:474-80.

17. Mott KE, Nuttall I, Desjeux P, Cattand P. New geographical approaches to control of some parasitic zoonoses. Bull World Health Organ 1995; 73:247-57.

18. Clements AC, Lwambo NJ, Blair L, Nyandindi U, Kaatano G, Kinung'hi S, et al. Bayesian spatial analysis and disease mapping: tools to enhance planning and implementation of a schistosomiasis control programme in Tanzania. Trop Med Int Health 2006; 11:490-503.

19. Miranda BAF, Melo C, Albuquerque JO, Bocanegra S, Souza HP, Santos RS, et al. Autômatos celulares aplicados à epidemiologia da esquistossomose em Pernambuco - uma análise comparativa do processo de coleta de moluscos. In: Anais do XXXI Congresso Nacional de Matemática Aplicada e Computacional. Belém: Sociedade Brasileira de Matemática Aplicada e Computacional; 2008. p. 630-6.

Submitted on $16 /$ Oct/2009

Final version resubmitted on $03 / \mathrm{Feb} / 2010$

Approved on 25/Feb/2010 